Article

\title{
Revisiting the Issues of Access to Higher Education and Social Stratification through the Case of Refugees: A Comparative Study of Spaces of Opportunity for Refugee Students in Germany and England
}

\author{
Marie-Agnès Détourbe ${ }^{1,2, *}$ and Gaële Goastellec ${ }^{3}$ \\ 1 INSA Toulouse, Centre des Sciences Humaines, 135 Avenue de Rangueil, 31077 Toulouse, France \\ 2 Laboratoire Cultures Education Sociétés LACES EA 7437, 3 ter place de la Victoire, \\ 33076 Bordeaux CEDEX, France \\ 3 LACCUS, OSPS, LIVES, University of Lausanne, 1015 Lausanne, Switzerland; gaele.goastellec@unil.ch \\ * Correspondence: detourbe@insa-toulouse.fr; Tel.: +33-561-559-483
}

Received: 26 July 2018; Accepted: 29 September 2018; Published: 3 October 2018

\begin{abstract}
This paper presents new insights into the relationship between inequality in access to higher education and social stratification through the analytical lens of refugees' access to high participation systems of higher education (HPS). Taking stock of the growing numbers of refugees and their increasing - yet still marginal—demand for accessing higher education, the paper analyses the specific statuses and rights they are granted, and how they combine in two European Higher Education Area HPS, England and Germany. The comparative analysis draws on the desk-based study of immigration and access to higher education policies and mechanisms for refugees in the two countries. The concept of assemblage is called upon to highlight how complex combinations of asylum, welfare and access to higher education policies lead to differential rights which create different spaces of opportunity for refugees with higher education aspirations. More generally, analysing how these rights intersect allows for a better understanding of inequalities in access to higher education.
\end{abstract}

Keywords: access to higher education; asylum; higher education; high participation systems; social inequality; social stratification; refugee

\section{Introduction}

The complex links between social stratification, inequality in access to higher education (henceforth, HE) and vertical and/or horizontal stratification in HE have been explored by social scientists from different theoretical and methodological perspectives: they shed light on the various facets and dynamics at play in high participation systems (Marginson 2016) of higher education (henceforth, HPS) across the world. This paper aims at presenting new insights into the relationship between inequality in access to higher education and social stratification through the analytical lens of refugees' access to higher education. Taking stock of the growing numbers of refugees and their increasing —yet still marginal—demand for accessing higher education, the paper analyses the complex dynamics at play between the specific rights and statuses they are granted and the way access to higher education is built as a (social) policy in two HPS, namely Germany and England.

First, an overview of research into the relationship between social stratification and inequality in access to HE is provided. Next, we suggest and defend a new approach of this multi-dimensional issue through the case of refugees. Then, the specific assemblages of refugee statuses and rights across three policy domains-asylum, welfare and access to HE-in Germany and England are mapped and a comparative analysis is conducted. Finally, we discuss the extent to which the issue of refugees' access 
to higher education in HPS illuminates conceptually the relationship between social stratification and inequality in access to HE.

\section{Setting the Research Context}

\subsection{Inequalities in Access to Higher Education and Stratification: A Multidimensional Research Object}

In HPS, successive widening participation policies and initiatives, along with increased social demand, have led to an increasingly differentiated student body. Whatever the rationales behind the massification of HE since World War II, from labour-market oriented logics to equity of opportunity philosophies, the massive rise in student numbers has led to further competition and stratification: students' socio-economic background, and to a lesser extent, gender, race and ethnicity, continue to be major drivers of inequality in access to HE, from admission to inclusion in the job market (e.g., Baum et al. 2010; Boliver 2016; Clancy 2010; Espenshade et al. 2004; Koucky et al. 2007; Vallet 2010). Further work has also shown that, even if massification first leads to a decrease in the overall level of social inequalities in access, once the share of one age group accessing HE has stabilised at a higher level, inequalities start increasing again (e.g., Goastellec and Välimaa 2016). Additionally, massification has generated a process of diversion within the $\mathrm{HE}$ sector, as inequalities have become more qualitative, with increased horizontal (institutional, disciplinary and study program) and vertical (degree) differentiation within HE (e.g., Lucas 2001; Marginson 2016; Shavit et al. 2007).

In trying to capture social stratification, studies in access to HE have mainly considered two dimensions. First, social stratification has been characterized, depending on the society, through variables such as parental education, income and profession-translated into various socio-economic classifications - but also ethnic, linguistic or geographical stratification (e.g., the POLAR categorization based on zones of residence in the UK) resulting in different indicators and/or indices combining some or all of these variables (e.g., Triventi 2013). Second, the internal stratification of the HE system has been analysed, sometimes as part of the very same studies: research work has highlighted the importance of $\mathrm{HE}$ geography on access (e.g., Frenette 2006; Metcalfe 2009; Singleton 2010; Voznesenskaya et al. 2004), as well as an increased differentiation and stratification of higher education institutions both horizontally and vertically (e.g., Altbach et al. 2017; Charles and Bradley 2002; Duru-Bellat et al. 2008). The stratification of secondary education systems has also been shown to lead to inequalities in HE (e.g., Clancy 2010; Goastellec and Välimaa 2016; Kerckhoff 2001). Additionally, variables such as programme-length (e.g., ISCED 5A, 5B, 6, 7 and 8), selectivity, intake quality (e.g., Alon and Tienda 2007; Burke and McManus 2011; Goastellec 2004) or quality of occupational outcomes have been analysed to characterize such differentiation and stratification, as well as a combination of these through various indicators or indices such as the "accessibility indicator" (Usher and Cervenan 2005; Usher and Medow 2010).

The links between social inequality and vertical and/or horizontal stratification in access to HE have thus been explored from different perspectives: depending on the scale of the studies (e.g., local, national, cross-national) and the chosen object (single or multiple courses at the same institution; full higher provision at a single institution or similar institutions nationally; international comparisons; etc.), research findings show that, beyond increased participation, HPS tend to lead to more differentiation and stratification in that the attained level and type of tertiary education, as well as the quality of occupational outcomes, are related to students' social origin.

Whether they are based on national or cross-national perspectives, many studies mainly bear on domestic student populations (Boliver 2018, p. 159) as the issue of access to HE is embedded in the long-term educational and occupational paths of the populations under study. In keeping with the focus of social inequality, they tend to look at either ends of the social spectrum in a given society - under-represented or disadvantaged groups on the one hand, and social and/or cultural elites on the other hand (e.g., Boliver 2016; Espenshade and Radford 2009) —in an attempt to unveil and highlight drivers of inequality or, on the contrary, levers of social mobility. Other studies focus 
on immigrants without considering refugees as a specific category of population endowed with customized administrative statuses and rights in many fields, including HE.

\subsection{Refugees' Access to Higher Education: New Insights}

\subsubsection{The Case of Refugees}

To analyse the relationship between social inequality in access to HE from a different angle, and at a time when migration dynamics increasingly intersect with access to HE issues (e.g., Détourbe 2018a; Goastellec 2018), this paper looks into the specific case of refugees. The 1951 Refugee Convention definition of the term "refugee," which is based on "well-founded fear of being persecuted for reasons of race, religion, nationality, membership of a particular social group or political opinion," is widely accepted and protection from persecution is recognized as a fundamental human right. However, asylum-seekers can access different refugee-related statuses from one country to the next, depending on how the multi-dimensional notion of "persecution" and its "well-founded" character are defined, evidenced and interpreted by the different parties. These statuses translate into specific legal and welfare rights. In a very insightful study of the way immigrants are categorized and granted differential rights, Könönen shows that "these categorizations reflect the aim of states to redefine the deservingness rather than the personal qualities or characteristics of migrants" (Könönen 2018, p. 55). The author adds that immigration laws "generat[e] forms of migration and [ ... ] differentiat[e] the position and rights of non-citizens after their entry into the immigration system" (ibid.). In this paper, we acknowledge this complexity and highlight the diversity of refugee and refugee-related statuses as well as the differential rights granted to those who are excluded from this status. However, whenever the focus is not on these differences, the term refugee is used in this paper as a generic category encompassing both refugee and refugee-related statuses. Refugees' access to HPS opens interesting research avenues at different levels and for different reasons.

First, refugees represent a marginal proportion of the HE student population worldwide ( $1 \%$ of the world's 25.4 million refugees access HE, UNHCR 2017), but a growing one in some European HPS where demand is rising steadily. The increasing number of young people both seeking asylum and aspiring to take up or pursue HE has led a growing number of countries to open access to HE more widely to this specific category of international (non-domestic) students: even if $85 \%$ of refugees still find shelter in developing regions (United Nations High Commissioner for Refugees 2017), the wide range of national and local initiatives which have cropped up across Europe (European Commission 2018; European University Association 2018) bears witness to the efforts made by higher education institutions to meet this rising demand. Recent European frameworks (e.g., ENIC-NARIC 2018; Lisbon Recognition Convention Committee 2017) have also aimed at setting standards so as to "make higher education accessible to all on the basis of capacity by every appropriate means," in keeping with the Convention on the Rights of the Child (1989) (cited in Dryden-Peterson and Giles 2010, p. 3; United Nations High Commissioner for Refugees 2015, p. 1). The rationales for welcoming refugees into HE vary and often combine into complex philosophies: it is sometimes presented as a key dimension of humanitarian help, following for instance George Sampaïo's (European Council on Refugees and Exiles 2016) claim that "higher education can maintain the hopes, help shelter and protect young men and women during crisis situations," and that "[e]ducated future leaders are necessary and we must prevent the creation of lost generations of academic graduates during wartime;" it can also follow more economic logics in ageing countries with a shortage of young, skilled labour (Morris-Lange and Brands 2016); in other cases, it can be dismissed as a threat to tightly controlled immigration numbers or run against elitist HE logics (Goastellec 2018).

Moreover, refugees are an interesting, albeit small, set of student population to look at in order to revisit the concept of social stratification and its relationship to inequality in access to HE: first, they stand at the margin of the abundantly studied "domestic population," with secondary or HE tracks in their home countries and HE aspirations in their host country-yet are considered as part of the 
under-represented or disadvantaged groups targeted by access to HE policies in several countries; therefore, they hold a very original status which combines "domestic" and "international" student rights, depending on the HPS; second, their migration is usually unchosen, so unplanned, therefore their very displacement undermines typical social reproduction patterns; and, third, they depend heavily upon social policies after their arrival in the host country, so beyond their social status as refugees, their probability to access $\mathrm{HE}$ is conditioned by how immigration and welfare policies intersect with HE policies, a dimension which has attracted little research attention so far.

By identifying some of the complex dynamics at play between the specific rights and statuses granted to refugees and the way access to HE is built as a (social) policy in two countries, the paper purports to answer the following research question: To what extent can the issue of refugees' access to higher education in HPS illuminate conceptually the broader issue of social stratification, and its relationship with access to higher education?

To answer this question, this paper maps and compares the different statuses and rights which refugees are granted in two European HPS: the aim is to understand how different spaces of opportunity are created through the specific assemblage of these rights across three policy domains, namely asylum, welfare and access to HE.

\subsubsection{Access to HE, Asylum and Welfare Policy Assemblages: An Analytical Lens}

Refugees have poor educational prospects (United Nations High Commissioner for Refugees 2017): for them, "education is rarely a smooth continuum from one level of schooling to another, and opportunities narrow at each step of the way" (Dryden-Peterson and Giles 2010, p. 4) so much so that less than $1 \%$ of them actually access HE. The variables which have been found to impinge on refugees' access to HE include "interrupted education, learning gaps, language, confusing application procedures, lack of accreditation of local programmes, distance from education opportunities, and costs" (UNHCR and Global Monitoring Report 2016, p. 10). Some researchers have highlighted the "inequalities in [refugees'] abilities to make choices, rather than the differences in the choices they make" (Dryden-Peterson and Giles 2010, p. 4), and how such inequalities can be analysed in terms of disempowerment, i.e. the denial of choice (Kabeer 2010, cited in Dryden-Peterson and Giles, ibid.). Since "power relations are crucial in defining the situation of refugees" (Dryden-Peterson and Giles, ibid.), these authors show that refugees do not fit in the neoliberal picture of students as "self-directed agents of all classes who can effectively navigate the postindustrial knowledge economy, able to both meet the skills needs of the economy and experience social mobility" (ibid.): their ability to make informed choices is hampered by "the unequal social relations and multiple discourses within which [their] aspirations and knowledge are embedded and formed" (Dougherty and Callender 2017, p. 8). In other words, their probability to access HE can be considered as "the product not so much of lesser desire or ability but of societal and institutional obstacles and exclusions that negatively shape disadvantaged students' aspirations, knowledge, and academic preparation" (ibid., p. 43).

The purpose of this paper is to unveil some of these "societal and institutional obstacles and exclusions" by looking more specifically at the type of administrative statuses they are offered and the associated rights they are granted in three policy domains: asylum, social welfare, and access to HE. We hypothesize that beyond an individual's categorization into a certain socio-economic stratum and their relative position within a specific social group, their probability to access HE is partly shaped by how these policy domains are assembled in specific national settings. Our analytical lens accordingly builds on the concept of assemblage, defined as "the coming together of different, heterogeneous parts to form a whole" (Müller 2015 cited in Al-Haque 2018, p. 8). Al-Haque (2018) elaborates on this very concept to account for "the complexities in the assemblage of actors enrolled around policies" (ibid.) when he studies how $\mathrm{HE}$ and immigration policies intersect with regard to internationalization in the Canadian context. In the same vein, Marginson (2016) claims that, in each country, the tendency to HPS - i.e., to ever-increasing participation to HE—is characterized by different "state-society-education assemblages" (2016, p. 264). 
In this paper, we elaborate further on this concept and argue that the specific assemblage of rights that refugees are granted across three policy domains make for different spaces of opportunity to access HE from one country to another. As highlighted by Könönen, "[i]mmigration law establishes legal statuses and respective legal identities [... ] through which states can regulate non-citizens' rights and access to various institutions and public resources" (2018, p. 55). Access to the refugee status, to HE and to welfare rights are a case in point: they "can be conceived as separate institutions, yet they are intertwined, as the type of legal status directly affects a person's eligibility for welfare service" (ibid., p. 56), and, as we show, their probability to access HE. By mapping and comparing the different statuses and rights granted to refugees in two different HPS, we purport to show that "[ $t$ ]hrough differences in the distribution of rights, including the differential inclusion in the welfare system, new kinds of legal hierarchies and subjects emerge into the sphere of citizenship" (ibid.). In other words, we aim to explore the extent to which, in a given society, social stratification draws on the definition of social goods — of which HE may or may not be part-and how these social goods can be accessed. Insofar as refugees can be said to stand outside their host country's social structures, the way their demand for accessing HE is met institutionally sheds light on the way access to HE rules are defined and structured in different settings, and the extent to which such access is considered as a universal right and potentially functions as a lever of social mobility.

\section{Materials and Methods}

The aim of this paper is to map and compare the different statuses and rights which refugees are granted in different countries so as to identify the spaces of opportunity which are created through the specific assemblage of these rights across three policy domains-asylum, welfare and access to HE. Accordingly, the main material for this desk-based research consists of primary sources, namely institutional written discourse outlining immigration, welfare, and access to HE policies in Germany and in England: they include reports, policy briefs or guidelines from institutional organisms providing official data or outlining procedures in any of these three domains (e.g., BAMF Federal Office for Migration and Refugees, Federal Office for Migration and Refugees; Higher Education Funding Council for England 2018; Home Office 2017; Lisbon Recognition Convention Committee 2017; Migration Observatory 2017; TestAS 2016; OECD 2017a, 2017b; United Nations Data 2018a, 2018b; Universities UK 2016b). We also drew on secondary documents which provide guidance to students and refugees for navigating the German or English access to HE, asylum and welfare systems (e.g., Refugee Council 2013, 2014, 2015, 2018a, 2018b; Refugee Support Network 2012; UK Council for International Student Affairs 2015): these documents, along with the (fairly limited but slowly developing) refugee access to HE literature (e.g., Berg 2018; Détourbe 2018a, 2018b; Dryden-Peterson and Giles 2010; Goastellec 2007; Morrice 2009, 2013; Morris-Lange and Brands 2016; Stevenson and Willott 2008; Zeiter-Grau and Goastellec 2017), and different non-academic sources such as NGOs, legal institutions, associations or the media (e.g., Barrons 2018; Law Library of Congress 2016; Pew Research Centre 2016; University World News 2018), allowed us to gain insights into the experience of asylum seekers with aspirations for HE. This rich collection of primary and secondary written resources, informed by previous qualitative research carried out on the topic by one of the authors (interviews with refugees, HE and asylum actors), allowed us to understand how different policies intersect, and the conditions under which the intersecting statuses and rights function as levers of opportunity or, on the contrary, obstacles for refugees with HE aspirations.

Germany and England were chosen for this study as they share a number of similarities while offering contrasted profiles in terms of state-education-society assemblages, as explained in the following section. They are both HPS, yet with different high participation trends and histories. In England, where education has been one of the devolved policy areas since 1992, successive various widening participation policies have been led under the aegis of the Higher Education Funding Council and through the Office for Fair Access (Dougherty and Callender 2017, p.15). The German HE system appears as a more recent HPS due to its historically strong post-secondary vocational sector: tertiary 
entry rates have been on the rise and the number of students entering HE is now higher than those entering the dual system of vocational training and education, with a particularly sharp increase in the early 2010s (Authoring Group Educational Reporting 2016; OECD 2017b). Moreover, the two countries share attention to refugee access to HE: in Germany, the DAFI programme is "the largest higher education scholarship program for refugees" (Dryden-Peterson and Giles 2010, p. 4), and, more recently, multiple refugee HE access programmes were created (European Students Union 2017; European University Association 2018); in England, multiple refugee associations have existed for years, coordinated via the Refugee Council, and various universities have set up refugee access schemes, for instance those belonging to the University of Sanctuary network. However, England and Germany have developed HPS and refugee access along different timelines, on different scales and against different social, economic and political contexts, more specifically regarding immigration. The comparative study of asylum, welfare and access to HE assemblages in these two countries therefore provides rich insights into the different spaces of opportunity for refugees with HE aspirations.

\section{A Comparative Analysis of Policy Assemblages in the English and the German HPS}

\subsection{An Overview of the HE and Immigration Landscapes in England and Germany}

Following Marginson (2016, p. 263), we consider that HPS are structured and shaped nationally: "Though the global dimension of higher education is increasingly important [ ... ] national aspects remain primary." To set the scene for the comparative analysis of specific assemblages of asylum, welfare and access to HE policies, a brief overview of the HE and immigration context in Germany and England is first drawn. In both cases, the logics of internationalization and widening participation are called upon as they represent central drivers in the increasing diversification of the student body, and they intersect with immigration dimensions at several levels.

\subsubsection{England}

In early 21st century England, immigration policies aimed at slowing down the steady growth in immigration numbers: between 2005 and 2017, the "international migrant stock" increased from 5,926,200 to 8,543,100 (United Nations Data 2018a), which led to significant public discontent. In 2010, Prime Minister David Cameron declared that he wished to reduce net immigration "to the tens of thousands," including asylum seekers, and the subsequent governments followed suit (Détourbe 2018b). This policy led to a significant drop in the number of "refugees and others of concern to UNHCR:" they were almost divided by two between 2005 and 2017, from 316,600 to 151,700 (ibid.). By refusing to leave international students out of the immigration net, the successive Conservative governments' immigration policies made it more difficult, and less desirable, for foreigners to come and study in the UK (Détourbe 2018b, p. 48; Morgan 2017). However, the country remains the second most sought HE destination in the international market with a high overall share of international students: $14 \%$ of undergraduate students, $38 \%$ of postgraduate students and $43 \%$ of doctoral students came from outside the UK during 2014-2015 (OECD 2017a). As international student fees are uncapped, they represent a growing share of higher education institutions' budgets: in 2014-2015, they amounted to $£ 4.2$ billion across the UK (ibid.). In parallel, England has striven to widen access internally to under-represented groups in the domestic population through various fair access and widening participation policies and initiatives led by the Office for Fair Access (OFFA) and the Higher Education Funding Council for England (HEFCE) which were merged into the Student Office in April 2018: the policies did improve access in that "in 2017, 20.4\% of 18-year-old English domiciled young people from low participation neighbourhoods entered higher education, compared with to 11.2\% in 2006," (Universities UK 2016b) and "UK domiciled black and minority ethnic (BME) students were $29 \%$ of all entrants to full-time first degrees in 2015-2016, despite these groups making up just 18\% of the 15-year-old population in the 2011 census in England" (Higher Education Funding Council for England 2018). The English HE system is also characterized by a high level of both vertical and horizontal stratification, with low, middle and 
high tariff institutions depending on entry requirements, prestige, and social advantage on the labour market (Futuretrack 2012). Even if the institutions are legally autonomous, home student numbers per institution and the level of tuition fees is managed centrally by the HEFCE. The cap on tuition fees gradually increased in the mid-2000s to make up for the cuts in public funding: in 2017-2018, they reached $£ 9,250$ on average for undergraduate home and European Union students, and they now represent $46 \%$ of the total higher education institution income; however, $92 \%$ of tertiary students receive support from public loans, scholarships or grants (Higher Education Funding Council for England 2018). With its slightly declining, but overall stable Gross Tertiary Enrolment Ratio of around 59\% (United Nations Data 2018a), the British HPS is therefore characterized by an internally (widening participation) and externally (internationalization) diversifying student body.

\subsubsection{Germany}

In Germany, the immigration policies devised by Angela Merkel's governments were characterized by a widening of immigration: the country's "international migrant stock" increased steadily from 2005 to 2017, from 10,299,200 to 12,005,700 immigrants. It was paralleled by a similar growth in the number of "refugees and others of concern to UNHCR" - from 784,000 in 2005 to 1,052,00 in 2017 (United Nations Data 2018b) — thereby reflecting Germany's political will to provide an answer to the migrant crisis (at least until the 2018 summer when the change of tone in political discourse over immigration issues contrasted sharply with previous discourse on welcoming asylum seekers). Moreover, highly skilled migrants represent an opportunity in that they can "help offset the decline of Germany's aging population" (Morris-Lange and Brands 2016, p. 11) and offer a solution to the "talent mismatch" that goes hand in hand with labour shortages (Thompson 2014). The fact that "the majority of asylum seekers are under 25 and [ . . ] have attended or had planned to attend university before they had to flee their home country" (Morris-Lange and Brands 2016, p. 11) adds to the already fairly positive context for widening access to refugees. The German HE system is characterized by a high proportion (49\%) of 25-34 year-olds with upper secondary or post-secondary non-tertiary vocational qualifications, whose employment rate is just as high as those with tertiary education (OECD 2017b). However, the number of students in German tertiary education increased by $23 \%$ between 2010 and 2014, which represents one of the sharpest growths in the OECD countries (ibid.). In parallel, Germany's international HE market share was stable over the 2010s: international students represent $18 \%$ of all first-time entrants into tertiary education and Germany has accordingly equipped itself with various national and regional mechanisms for recognizing foreign students' prior qualifications and non-degree bridging programmes for taking these students to the required level for degree study programmes. Such a "proactive public policy" approach (Jungblut 2017) has undoubtedly made it easier for the Länder and the universities to design fast and efficient answers to refugees' demand for HE. Overall, the German HE system appears as a fairly homogeneous, predominantly publicly-funded HPS based on a combination of Bundesländer and central federal responsibility which has developed following both human capital and solidarity rationales: with a steadily increasing Gross Tertiary Enrolment Ratio (from over 60\% in 2013 to over 66\% in 2015, United Nations Data 2018b), it seems to have "found its own HPS pathway" (Marginson 2016, p. 263) recently and the massive response of German higher education institutions to widening access to refugees represents a key dimension of the global picture (Berg 2018; Unangst and Streitwieser 2018).

In the next section, the asylum, social welfare and access to HE policy assemblages in England and Germany are mapped against each HPS: the way different rights are combined and intersect across these different policy fields shape different spaces of opportunity for refugees with HE aspirations.

\subsection{Mapping the Asylum, Social Welfare and Access to HE Assemblage in England}

In England, as in the other parts of the UK, immigration, nationality and border control laws are under the central responsibility of the Home Office. Following a sharp increase in asylum applications in the early 2000s, the successive governments tightened immigration rules, cutting the number of grants 
of asylum to "remove the perception that the UK is a 'soft touch' for asylum seekers," and made it harder for immigrants who wish to enter the UK for "undesirable purposes" (Law Library of Congress 2016). The 2014 Immigration Act removed the right of appeal to different categories of applicants: in 2017, 68\% of asylum claims were rejected, $28 \%$ accepted, and 1\% of asylum applicants were granted Humanitarian Protection or Discretionary Leave (Refugee Council 2018a). Less than one third of asylum applicants actually access refugee status then, and a minority are granted different refugee-related statuses with more limited citizenship rights (Table 1): Humanitarian Protection (henceforth, HP) is defined as "a form of immigration status granted by the Home Office to a person who it decides has a need for protection but who does not meet the criteria for refugee status," and Discretionary Leave to Remain (henceforth, DLR) is yet another immigration status granted "to a person who the Home Office has decided does not qualify for refugee status or humanitarian protection but where there are other strong reasons why the person needs to stay in the UK temporarily" (Refugee Council 2018b).

As in most countries, asylum seekers cannot choose where they live while their case is being processed; they are granted basic accommodation as part of the "initial accommodation procedure," and get "furnished accommodation including utilities, a weekly cash allowance to cover essential living needs [from the UK Border Agency], and free access to healthcare" (Law Library of Congress 2016) as they are not allowed to work while their case is being processed. Only when they do access refugee or refugee-related statuses do they become eligible to "Integration loan" first (UK Council for International Student Affairs 2015; Refugee Council 2015, p. 5), and then mainstream welfare benefits (e.g., Job Seekers' Allowance, Employment Support Allowance or Income Support). Similarly, refugees and people with HP are eligible to permanent social housing, Integration Loans and Housing benefit whereas asylum seekers and people with DLR are excluded from these rights (Table 1). An interesting example of the extent to which the different "legal statuses and respective legal identities" can be used by the states to "regulate non-citizens' rights and access to various institutions and public resources" (Könönen 2018, p. 55) is the March 2017 Home Office decision to grant Refugee Status and five years' Limited Leave to Remain to Syrians coming under the Syrian Vulnerable Person Resettlement Scheme (they were previously granted HP status). In a written Ministerial Statement, the Secretary of State for the Home Department justified this change by declaring:

[W]hile Humanitarian Protection recognises the need an individual has for international protection, it does not carry the same entitlements as refugee status, in particular, access to particular benefits, swifter access to student support for Higher Education and the same travel documents as those granted refugee status. [ . . ] We think it is right to change the policy and now is the right time to make this change. (Home Office 2017)

Beyond social welfare benefits, the different refugee statuses open different spaces of opportunity to access HE from a policy perspective (Table 1). At a national level, even if all immigrants are entitled to study, student status and the corresponding tuition fees are conditioned by the legal refugee status: only "young people with Refugee Status, and those with Indefinite Leave to Remain (ILR) or Humanitarian Protection (HP) status who have been ordinarily resident in the UK for three years are entitled to home fees" (Refugee Support Network 2012, p. 10). In this context, both asylum seekers and people with refugee-related statuses who have not been resident in England for three years face a major financial obstacle when they try to access HE: not only do they need to pay international tuition fees, but they are not eligible to mainstream student support (ibid.). Asylum seekers are offered an intermediate, temporary solution: if they study part-time and follow ESOL (English for Speakers of Other Languages) courses for instance, they are entitled to standard welfare benefits, housing benefit and council tax for up to nine months (UK Council for International Student Affairs 2015). Even when refugees are eligible to home tuition fees, these are still so high—an average $£ 9,250$ for undergraduate studies — that funding represents a major obstacle. Moreover, since 2005, the Refugee Status is only awarded for five years (potentially followed by the Indefinite Leave to Remain status), which has made many higher education institutions across England "less willing to take on young refugees who do not have a full three or four years of refugee status remaining" (Stevenson and Willott 2008, in Refugee Support Network 2012, p. 11). 
Table 1. Administrative refugee status and corresponding welfare and student rights in England.

\begin{tabular}{|c|c|c|c|c|c|c|c|}
\hline Asylum Status & $\begin{array}{c}\text { Assigned } \\
\text { Residence }\end{array}$ & Welfare Benefits & $\begin{array}{c}\text { Right to } \\
\text { Work }\end{array}$ & Student Status & $\begin{array}{c}\text { Right to } \\
\text { Study }\end{array}$ & Admissions & Fainstream Student \\
Support
\end{tabular}


As a result, even if refugees are an explicit target for widening participation and fair access agreements and programmes run centrally by the Office for Students in England, access to HE is very much the responsibility of individual higher education institutions: HEIs are free to set their own academic requirements, design their own admission processes, and even choose to apply home fees to asylum seekers or applicants with the DLR status. Successive policy initiatives promoting "student information provision; outreach [ . . ] ; student financial aid; affirmative action or contextualisation in higher education admissions; etc." (Dougherty and Callender 2017, p. 2) have indeed been implemented at different levels and on various scales by English HEIs. Yet, very few elite and high-tariff universities have actually contextualized their admission processes and lowered their academic requirements for students from under-represented groups and disadvantaged backgrounds (The Guardian 2017) so disparities have been found to be the greatest at these institutions (Higher Education Funding Council for England 2018). Other HEIs have set up targeted admissions procedures and scholarships for refugees, for instance those that have joined the University of Sanctuary network (http:/ / universities.cityofsanctuary.org). Therefore, from one HEI to the next, a refugee will find that the official academic documentation obtained through UKNARIC (National Academic Recognition Centre), the British organization in charge of recognizing prior learning and qualifications in line with European standards, is processed differently and more or less contextualized, despite national incentives from the new Office for Students to do so as part of the "Opportunity for Everyone" campaign. Refugee applicants, like all other international applicants, are also required to meet standard language requirements which, beyond visa requirements (B2 on the Common European Framework for Languages), are set individually by each HEI and typically certified through IELTS exams (International English Language Testing System).

In an already fragmented asylum policy context which offers differential rights according to the legal refugee status, the probability for refugees to access HE in the very hierarchical English HPS is therefore highly dependent on the institution's status as a low, middle or high-tariff institution (depending on the level of academic requirements as managed by UCAS through tariff points), and on the existence of targeted scholarship programmes and specific contextualized admission processes, which are only slowly being developed (Boliver et al. 2017; Dougherty and Callender 2017; The Guardian 2017). Overall, the probability for refugees to access HE in England is tightly conditioned by access to (and the ability to make informed choices from) customized and well-informed advice, information and guidance about each HEI's requirements and targeted support (including funding): more generally, it involves being able to navigate the administrative nooks and crannies of the combined asylum, welfare and HE systems.

\subsection{Spaces of Opportunity for Refugees in Germany}

Germany is a federal structure, with different responsibilities shared between the sixteen Bundesländer governments and the central federal government. Asylum is managed centrally by the Federal Office for Migration and Refugees (BAMF). Once asylum seekers set foot in Germany, the Federal Office checks through the European database Eurodac that their asylum case is not already being processed by another European State, in keeping with the Dublin regulation. They are given a proof of arrival (Ankunftsnachweis) — their first official document on German soil—and are assigned to an administrative district of residence (Wohnsitzauflage) following the EASY quota system which "ensures suitable, fair distribution among the Federal-Länder" and is decided on annually by the Federal-Länder commission (BAMF Federal Office for Migration and Refugees, p. 9). Asylum applicants are not allowed to work while their case is being processed: they receive "basic benefits for food, housing, heating, clothing, healthcare and personal hygiene" (BAMF Federal Office for Migration and Refugees, p. 10), in keeping with the Asylum-Seekers' Benefits Act (Asylbewerberleistungsgesetz). The social benefits provided by the State are meant to cover their basic needs until a final decision is made by the BAMF. Meanwhile, they are not eligible for government-funded student benefits (Morris-Lange and Brands 2016, p. 11). Refugees can apply to general welfare benefits once they have 
resided in Germany for 15 months (it used to be four years) after the date they originally applied for asylum, or once they are officially entitled to protection (ibid.). The asylum process can be quite long though-over six months on average and sometimes over a year (Morris-Lange and Brands 2016, p. 11) - as the number of asylum cases which the German Federal Office has to deal with has been on the rise over the last decade: for instance, over 745,000 immigrants lodged a file for asylum in Germany in 2015 (European Students Union 2017, p. 25). Asylum seekers are required to remain in their district of residence for three months and are considered as "asylum applicants" as long as their claim has not been decided on. If they case is accepted, they can be granted different legal statuses (see Table 2): "persons entitled to protection" (with three forms of protection i.e., "entitlement to asylum," "refugee protection" or "subsidiary protection") or "persons entitled to remain" (following a "ban on deportation") (BAMF Federal Office for Migration and Refugees, p. 2). While the asylum-seeker status stands apart as it is a transitory one, the different refugee and refugee related statuses actually open the same social welfare rights under the same conditions, in line with the Hartz IV unemployment and welfare package.

Moreover, access to HE for refugees is characterized by the fact that "technically, access to higher education is less restricted in Germany than in many other European countries" (Morris-Lange and Brands 2016, p. 11) since "more than half of all HEIs do not require a special status of asylum for admission to study" (European Students Union 2017, p. 34). In fact, not only are tuition fees very low at German higher education institutions for all students (from $100 €$ to $300 €$ ), but most HEIs-universities (universitäten), universities of applied sciences (fachhochschulen) or universities of Art and Music (kunsthochschulen and musikhochschulen) —offer various study options to immigrants, regardless of their asylum or refugee status (European Students Union 2017, p. 27). Another central characteristic of German HE is that it has historically been under the authority of the sixteen Länder governments, but some dimensions are now managed under the combined authority of the Länder and the Federal Ministry of Education and Research. As a result, refugees have access to nation-wide services and mechanisms such as TestAs, a centrally-run standard academic aptitude test for foreign students which "examines both the general and subject-related abilities for academic studies" (European Students Union 2017, p. 29) which refugees can take for free. They can also benefit from Uni-Assist, an association founded in 2003 that "evaluates secondary-school certificates and centrally handles applications of international students to HEIs" (European Students Union 2017, p. 28), and attend two-semester preparatory courses-including intensive German language classes-at public institutions (Studienkollegs) which were set up throughout Germany to help foreign students who did not meet HEI academic entry requirements at undergraduate level. Moreover, a common policy for "Access and Admission to Institutions of Higher Education for Applicants who are Unable to provide Evidence of a Higher Education Entrance Qualification Obtained in their Home Country on Account of their Flight" was decided on in December 2015 at the Standing Conference of the Ministers of Education and Cultural Affairs (European Students Union 2017, pp. 28-29).

Beyond existing mechanisms for foreign students, multiple targeted access to HE initiatives for refugee students were developed at national, Land and local levels (Berg 2018; European Students Union 2017, pp. 25-42; Unangst and Streitwieser 2018): eleven out of sixteen Länder launched programs aimed at widening access to German HEIs for refugees in various ways and with variable amounts of funding (European Students Union 2017, p. 32). Many volunteer and student-led initiatives were thus developed, drawing on both existing local international student offices, and targeted Federal government and Land funding. Beyond the long-established DAFI programme for refugees, extensive Federal Ministry of Education and Research (BMBF) programmes like "Integra" (Integrating Refugees in Degree programmes) or "Welcome" (Welcome-Students Helping Refugees) were launched in cooperation with the German Academic Exchange Service (DAAD), and extra places at Studienkollegs were funded. As a result, refugees who wish to access HE in Germany can do so through different pathways and benefit from converging and comprehensive support from higher education institutions, Länder and the federal ministry. 
Table 2. Administrative refugee status and corresponding welfare and student rights in Germany.

\begin{tabular}{|c|c|c|c|c|c|c|c|c|}
\hline Asylum Status & $\begin{array}{l}\text { Assigned } \\
\text { Residence }\end{array}$ & $\begin{array}{l}\text { Welfare } \\
\text { Benefits }\end{array}$ & Right to Work & $\begin{array}{l}\text { Student } \\
\text { Status }\end{array}$ & Right to Study & Admissions & Fees & $\begin{array}{c}\text { Mainstream Student } \\
\text { Support }\end{array}$ \\
\hline Asylum applicant & $\begin{array}{l}\text { Yes (at least for } \\
3 \text { months in } \\
\text { assigned Land; for } \\
\text { 1st year in } \\
\text { Germany) }\end{array}$ & $\begin{array}{l}\text { Asylum-seeker's } \\
\text { benefits }\end{array}$ & $\begin{array}{l}\text { Not for the first } \\
3 \text { months/while } \\
\text { in reception } \\
\text { centre, }\end{array}$ & \multirow{3}{*}{$\begin{array}{c}\text { International } \\
\text { student }\end{array}$} & Yes & \multirow{3}{*}{$\begin{array}{c}\text { HEI level decision: } \\
\text { Standard HE } \\
\text { qualifications \& language } \\
\text { requirements } \\
\text { Subject to international } \\
\text { student quotas }\end{array}$} & \multirow{3}{*}{$\begin{array}{l}\text { National fees } \\
\text { (100 to } 300 €)\end{array}$} & \multirow{3}{*}{$\begin{array}{c}\text { Yes } \\
\text { Targeted scholarships } \\
\text { at HEI, Land and } \\
\text { federal levels } \\
\text { "In-kind" support at } \\
\text { HEI level }\end{array}$} \\
\hline $\begin{array}{l}\text { Entitled to } \\
\text { protection }\end{array}$ & \multirow{2}{*}{ No } & \multirow{2}{*}{$\begin{array}{l}\text { Unemployment } \\
\text { and welfare } \\
\text { rights (Hartz IV) }\end{array}$} & Yes & & \multirow[t]{2}{*}{$\begin{array}{l}\text { Yes }+ \text { access to } \\
\text { Studienkolleg }\end{array}$} & & & \\
\hline Entitled to remain & & & $\begin{array}{l}\text { Yes (with } \\
\text { permission) }\end{array}$ & & & & & \\
\hline
\end{tabular}


However, refugees are handled as international students from an administrative point of view in HEIs (Berg 2018), which means that they are "subject to general admissions requirements for international students" (European Students Union 2017, p. 29): being included in international student admission quotas therefore entails high competition with other international students to access degree programmes. Moreover, following the 2006 General Treatment Act, HEIs are not allowed to give refugees privileged access to highly regulated courses with a numerus clausus such as medicine (ibid.). Last, most undergraduate courses at German HEIs are offered in German, and a high level of proficiency is required (C1 on the Common European Framework for Languages, European Students Union 2017, p. 30) to enrol in a degree course, while places in language courses are lacking (European Students Union 2017, p. 28). Overall, the combination of low tuition fees, flexibility of access to HE whatever the legal asylum status, opportunities to qualify for a little stratified German HE sector thanks to pre-existing policies and structures for international students, as well as general welfare support, has shaped so far a fairly open space of opportunity for accessing HE. However, the high academic and language requirements (Unangst and Streitwieser 2018) remain a major obstacle.

\section{Discussion: New Insights into the Relationship between Social Stratification and Access to Higher Education and Policy Implications}

\subsection{Spaces of Opportunity for Refugees in England}

In England, the combined tight immigration and asylum rules, high fees and few access programmes targeting refugees at HEIs make for narrow spaces of opportunity. The immigration and asylum context is currently difficult and not likely to improve with the Brexit. Moreover, the English HPS is no longer expanding internally, as "an above-average proportion of adults have a tertiary qualification," mostly at bachelor's degree level (OECD 2017a, p. 4), which means that there is no need for extra qualified labour. The participation rate among Black and Ethnic Minority students has improved thanks to widening participation policies and initiatives, but "socio-economic disadvantage continues to be the most significant driver of inequality in terms of access to and outcomes from higher education," regardless of ethnicity or gender (Universities UK 2016a, p. 4). Despite official discourse about meritocratic access, a "sponsorship model of selection" prevails: it means that "networks and the right kinds of social and cultural capital [ ... ] are more important in England than ability and effort" (Mountford-Zimdars 2014, p. 95), which makes for poor prospects for refugees who need to build new social and cultural capitals in their host country. Finally, tuition fees now represent almost half of HEIs' income nationally, and English HEIs are most likely going to keep developing international student recruitment at master's degree and doctoral level as their fees represent a major source of funding. Access to HE for refugees therefore depends highly on local initiatives like the "University of Sanctuary" movement, or other forms of targeted support based on humanitarian and solidarity rationales in a social, political and economic context which currently favours competition and market logics (Halsey and $\mathrm{O}^{\prime}$ Brien 2014). Even if no national statistics are currently available regarding refugee student numbers in English HE, they are likely to remain marginal.

\subsection{Spaces of Opportunity for Refugees in Germany}

In Germany, the specific combination between immigration, welfare and access to HE policies, added to the fact that this HPS is still growing with "the largest increase [ . . ] in first-time entrants across OECD and partner countries between 2005 and 2015" (OECD 2017b), makes for a good structural probability for refugees to access HE in the fairly short run after they first set foot in the country and lodge a file for asylum: a survey led by the German Rectors Conference (HRK) indicated that in 2017, an estimated 1,140 refugees were enrolled at German universities (Unangst and Streitwieser 2018). Moreover, access is most likely to take place in non-degree bridging programmes including German language courses. However, recent research (Berg 2018) shows that access to welfare benefits is subject to variations from one land to the next, and from one city to the next, thus introducing an additional 
level of variability in access opportunities. Moreover, the changing political landscape following the 2018 general elections in Germany could lead to a less favourable context for immigrants seeking asylum in Germany. The strong will which HE authorities at national, Länder and local levels have displayed so far for welcoming refugees, combined with the country's economic needs for qualified labour, could maintain good access to HE conditions though. The challenge lies in the successful inclusion of the future refugee graduates into the German labour market and society in the longer run, which is fairly likely to happen as recent statistics show that "rates of participation in education by people with and people without immigration backgrounds have moved closer together" over the last decade (Authoring Group Educational Reporting 2016, p. 8).

\subsection{New Insights into the Relationship between Social Stratification and Access to Higher Education and Policy Implications}

The comparison between the way access to HE for refuges is built in two different HPS contexts sheds new light on the relationship between social stratification and access to HE. Refugees represent a growing, albeit marginal, student category in an increasingly diversifying HPS student body. The conditions under which they are given access to HE provides a different perspective for understanding how social stratification leads to "overall social differences associated with inequalities of wealth, power, prestige or knowledge" (Coulangeon 2010, our translation).

Refugees were born and raised in another social structure, yet the cultural (including academic), social and economic capitals they held back home are often partially or fully lost in the forced displacement to their new country (Dimitriadou 2006; Morrice 2009, 2013; Stevenson and Willott 2008)—as shown for instance through the fact that it is difficult for them to resume or start HE studies at an equivalent level of academic qualifications. However, much capital is transferred, which may vary from one refugee to the next, and whatever its impact on the probability of access, everything else being equal, we argue that the administrative place they are assigned to in the social structure of their host country determines their structural possibility to access $\mathrm{HE}$, as well as its temporality, to a large extent. The refugee status is linked to the safety and solidarity rationales defined by the 1951 Geneva Convention, so that refugees stand apart and stand out from other immigrants: they are granted different welfare rights, and different forms of access to citizenship (Könönen 2018) from those offered to other immigrants, as visible through the categories such as "Humanitarian Protection" or "Indefinite Leave to Remain" in England, or "Asylum Tolerated" in Germany which were created for those who are refused the official refugee status. The differential citizenship rights refugees are granted through different assemblages of welfare and citizenship rights can therefore be understood as "a new pattern of stratification related to immigration and citizenship status" (Sainsbury and Morissens 2012, p. 130): when combined with access to HE rights, they can even produce inequality in access and contribute to creating a form of "market citizenship" whereby "the allocation of citizenship rights [is] based on an individual's economic power and participation in the labour market" (Brodie 1997, cited in Breanne et al. 2017, p. 1), both dimensions being more or less directly related to an individual's participation in HE.

Our research shows that this administratively built citizenship combines variously with access to HE policies to create different spaces of opportunity for refugees who want to study, with different timelines. It means that even if refugees have strong personal motivations for education (Refugee Support Network 2012, p. 7), and meet standard entry requirements (i.e., level of academic qualifications and language skills), their probability to access HE in a specific HPS is systematically shaped at the crossroads between national asylum, social welfare and access to HE policies. It is conditioned by student categorization (domestic/international), and how it is associated with different political territories but also citizenship categories, which raises the issue of the territorial boundaries of social justice in access, and leads us to formulate two concluding comments.

First, as refugee students share both international and home student characteristics, policy actions aiming at improving access should combine internationalization and widening participation logics, which also involves answering questions about the role of HE and the type of HE one wants to build, 
beyond the case of refugees: Should HE be built as a social good or a commodity subject to competitive entry? What is an acceptable level of fees and should alternative funding mechanisms exist to make up for the lack of economic capital? Should HE be homogeneously accessible on a given regional, national, neo-regional territory or universally? What type of targeted advice, information and guidance could or should be provided to make up for the lack of cultural capital and empower refugees? Should contextualized admissions processes be set up and entry requirements adapted to open access to students with more heterogeneous academic profiles? More generally, to what extent could or should customized forms of support and access be developed within mass education systems such as HPS so that the rationale for access should be "to unlock future potential rather than to reward past success" (Hillman 2017, p. 9) through evaluation of past qualifications?

Second, social policies intersect with HE policies to produce differentiated spaces of access to HE not only for refugees, but also, more broadly, for national students, especially because social benefits are not always fully compatible with studying in HE: for domestic students too, the "differential inclusion [of citizens] in the welfare system" leads to "new kinds of legal hierarchies" (Könönen 2018, p. 56) which impact access to HE. As a result, an individual's position in the social structure not only undermines their probability to access HE in relation with their own resources, as research has largely shown, but also in relation to their social categorization in the welfare organization. Therefore, the (re)production of social stratification through the political organization of inequalities in access to $\mathrm{HE}$ also lies at the crossroads between these different policy domains.

This research therefore sheds light on the fact that some "societal and institutional obstacles and exclusions that negatively shape disadvantaged students' aspirations, knowledge, and academic preparation" (Dougherty and Callender 2017, p. 43) are created not only in different, parallel policy fields, but also in the way they are assembled and they intersect for certain categories of citizens in national settings. From a policy perspective, providing refugees-as well as other less visible under-represented groups - with an adequate administrative and social position through adapted policy assemblages of statuses and rights appears as a necessary, albeit insufficient, step in empowering them to make the HE choices which best fit their aspirations:

Even if growing access to higher education by less-advantaged groups does not produce equality, it does give those groups access to forums and powers that bring immediate individual benefits and better position those groups for the next stage in their struggle for equality. (Dougherty and Callender 2017, p. 46)

Author Contributions: Conceptualization, M.-A.D. and G.G.; Formal analysis, M.-A.D. and G.G.; Investigation, M.-A.D.; Methodology, M.-A.D. and G.G.; Validation, M.-A.D. and G.G.; Writing-original draft, M.-A.D. and G.G.; and Writing-review and editing, M.-A.D. and G.G.

Funding: This research received no external funding

Conflicts of Interest: The authors declare no conflict of interest.

\section{References}

Al-Haque, Rashed. 2018. Canada's Citizenship, Immigration, and International Education Policies: A Messy Assemblage of Actors and Priorities. In Inclusion through Access to Higher Education: Exploring the Dynamics between Access to Higher Education, Immigration and Languages. Edited by M.-A. Détourbe. Rotterdam and Boston: Sense Publishers/Brill, pp. 3-20. ISBN 978-94-6351-225-1.

Alon, Sigal, and Marta Tienda. 2007. Diversity, opportunity, and the shifting meritocracy in higher education. American Sociological Review 72: 487-511. [CrossRef]

Altbach, Philip G., Liz Reisberg, and Hans de Wit, eds. 2017. Responding to Massification. Differentiation in Postsecondary Education Worldwide. Rotterdam: Sense Publishers/Brill, ISBN 9789463510813.

Authoring Group Educational Reporting. 2016. Education in Germany 2016. In An Indicator-Based Report Including an Analysis of Education and Migration. Bielefeld: AGER. Available online: https://www.bmbf.de/files / 6001820e_kf-englisch_barrierefrei.pdf (accessed on 16 September 2018). 
BAMF (Federal Office for Migration and Refugees). 2016. The Stages of the German Asylum Procedure. An Overview of the Individual Procedural Steps and the Legal Basis. Available online: https://www.bamf.de/SharedDocs/Anlagen/EN/Publikationen/Broschueren/das-deutscheasylverfahren.pdf?_blob=publicationFile (accessed on 15 July 2018).

BAMF (Federal Office for Migration and Refugees). 2018. Qualification Standards of Asylum Applicants in 2017. Available online: http:/ / www.bamf.de/SharedDocs/Anlagen/EN/Publikationen/Kurzanalysen/ kurzanalyse_soko_03-2018.html?nn=1449080 (accessed on 15 July 2018).

Barrons, Geneviève. 2018. Why displaced people are being failed by Higher Education. University World News, May 28. Available online: http:/ / www.universityworldnews.com/article.php?story=2018052211400745 (accessed on 15 July 2018).

Baum, Sandy, Jennifer Ma, and Kathleen Payea. 2010. Education Pays. The Benefits of Higher Education for Individuals and Society. New York: College Board Advocacy and Policy Center.

Berg, Jana. 2018. A New Aspect of Internationalisation? Specific Challenges and Support Structures for Refugees on Their Way to German Higher Education. In European Higher Education Area: The Impact of Past and Future Policies. Edited by Adrian Curaj, Ligia Deca and Remus Pricopie. New York: Springer Open, pp. 219-36. [CrossRef]

Boliver, Vikki. 2016. Exploring ethnic inequalities in admission to Russell group universities. Sociology 50: 247-66. [CrossRef] [PubMed]

Boliver, Vikki. 2018. Afterword. In Inclusion through Access to Higher Education: Exploring the Dynamics between Access to Higher Education, Immigration and Languages. Edited by M.-A. Détourbe. Rotterdam and Boston: Sense Publishers/Brill, pp. 159-60. ISBN 978-94-6351-225-1.

Boliver, Vikki, Stephen Gorard, and Nadia Siddiqui. 2017. A more radical approach to contextualized admissions. In Where Next for Widening Participation and Fair Access? New Insights from Leading Thinkers. London: HEPI/Brightside, pp. 23-8. ISBN 978-1-908240-29-3.

Breanne, L. Grace, Stephanie J. Nawyn, and Betty Okwako. 2017. The right to belong (if you can afford it): Market-based restrictions on social citizenship in refugee resettlement. Journal of Refugee Study 31: 42-62. [CrossRef]

Brodie, Jeanine. 1997. Meso-discourses, state forms and the gendering of liberal-democratic citizenship. Citizenship Studies 1: 223-42. [CrossRef]

Burke, Penny Jane, and Jackie McManus. 2011. Art for a few: Exclusions and misrecognitions in higher education admissions practices. Discourse: Studies in the Cultural Politics of Education 32: 699-712. [CrossRef]

Charles, Maria, and Karen Bradley. 2002. Equal but separate? A cross-national study of sex segregation in higher education. American Sociological Review 67: 573-99. [CrossRef]

Clancy, Patrick. 2010. Structural diversification: does it matter? In Access and Equity. Comparative Perspectives. Edited by Heather Eggins. Rotterdam: Sense Publishers, pp. 103-20. ISBN 978-94-6091-184-2.

Coulangeon, Philippe. 2010. Stratification sociale. In Les 100 Mots de la Sociologie. Edited by Serge Paugam. Paris: PUF, Que sais-je, pp. 101-2. ISBN 9782130574057.

Dimitriadou, Anastasia. 2006. The Formation of Social Capital for Refugee Students: An Exploration of ESOL Settings in Two Further Education Colleges. Educate 4: 31-45.

Détourbe, Marie-Agnès, ed. 2018a. Inclusion through Access to Higher Education: Exploring the Dynamics between Access to Higher Education, Immigration and Languages. Rotterdam and Boston: Sense Publishers/Brill, ISBN 978-94-6351-225-1.

Détourbe, Marie-Agnès. 2018b. Les universités britanniques et leur rapport au monde: Les enjeux de l'internationalisation de la population étudiante [Internationalization strategies in British Universities]. Observatoire de la Société Britannique 20: 37-66. [CrossRef]

Dougherty, Kevin J., and Clare Callender. 2017. English and American Higher Education Access and Completion Policy Regimes: Similarities, Differences and Possible Lessons. Working Paper n. 24. London: Centre for Global Higher Education, August. Available online: http://www.researchcghe.org/publications/english-and-americanhigher-education-access-and-completion-policy-regimes-similarities-differences-and-possible-lessons / (accessed on 15 July 2018).

Dryden-Peterson, Sarah, and Wenona Giles. 2010. Higher Education for Refugees. Refuge, Canada's Journal on Refugees 27: 3-9. Available online: https://refuge.journals.yorku.ca/index.php/refuge/article/view/34717/ 31547 (accessed on 15 July 2018). 
Duru-Bellat, Marie, Annick Kieffer, and David Reimer. 2008. Patterns of Social Inequalities in Access to Higher Education in France and Germany. International Journal of Comparative Sociology 49: 347-68. [CrossRef]

European Council on Refugees and Exiles. 2016. Highlighting the Need to Prioritise Access to Higher Education in Humanitarian Crises. Available online: http:/ / www.ecre.org/highlighting-the-need-to-prioritise-accessto-higher-education-in-humanitarian-crises / (accessed on 15 July 2018).

Espenshade, Thomas J., and Alexandria W. Radford. 2009. No Longer Separate, Not Yet Equal: Race and Class in Elite College Admission and Campus Life. Princeton: Princeton University Press, ISBN 9780691141602.

Espenshade, Thomas J., Chang Y. Chung, and Joan L. Walling. 2004. Admission Preferences for Minority Students, Athletes, and Legacies at Elite Universities. Social Science Quarterly 85: 1422-46. [CrossRef]

Frenette, Marc. 2006. Too far to go on? Distance to school and university participation. Education Economics 14: 31-58. [CrossRef]

ENIC-NARIC. 2018. Recognise Qualifications Held by Refugees-Guide for Credential Evaluators. Available online: http:/ / www.enic-naric.net/recognise-qualifications-held-by-refugees.aspx (accessed on 15 July 2018).

European Students Union. 2017. Refugees Welcome? Recognition of Qualifications Held by Refugees and Their Access to Higher Education in Europe. Country Analyses. Brussels: ESU. Available online: https:/ / www.esu-online.org/ ?news=new-study-refugees-access-higher-education-europe (accessed on 15 July 2018).

European Commission. 2018. Higher Education for Migrants and refugees. Available online: http:/ / ec.europa. eu/education/policy/migration/higher-education-refugees_en (accessed on 11 September 2018).

European University Association. 2018. Refugee Welcome Map. Available online: https:/ /www.eua.eu/index. php?option=com_content\&view=article\&id=541:refugees-welcome-map\&catid=101:projects\&Itemid=575 (accessed on 11 September 2018).

Futuretrack. 2012. A New Classification of Higher Education Institutions. Warwick: Higher Education Careers Service Unit. Available online: https://www.hecsu.ac.uk/assets/assets/documents/Futuretrack_Summary_2012_ -_A_new_classification_of_HEIs.pdf (accessed on 15 July 2018).

Goastellec, Gaële. 2004. Entre politique des quotas et égalité: l'université de Californie à Berkeley. Cahiers Internationaux de Sociologie N 116: 141-64. [CrossRef]

Goastellec, Gaële. 2007. Refugees' Access to Higher Education. Encyclopedia of International Higher Education Systems and Institutions.

Goastellec, Gaële. 2018. Refugees' Access to Higher Education in Europe. Comparative Insights on a New Public Issue. In Inclusion through Access to Higher Education: Exploring the Dynamics between Access to Higher Education, Immigration and Languages. Edited by M.-A. Détourbe. Rotterdam and Boston: Sense Publishers/Brill, pp. 21-38. ISBN 978-94-6351-225-1.

Goastellec, Gaële, and Jussi Välimaa. 2016. Expliquer les inégalités d'accès aux diplômes en Finlande et en Suisse (1950-2004): Des structures scolaires aux politiques sociales. Education et Société 38: 105-21. [CrossRef]

Halsey, John, and Kenneth O'Brien. 2014. Education Markets in English and American Universities. In Higher Education in the UK and the US. Converging University Models in a Global Academic World? Edited by Sarah Pickard. Leiden, Boston: Brill, pp. 35-58. ISBN 978-90-04-26276-8.

Higher Education Funding Council for England. 2018. Student Characteristics. Available online: http:/ / www. hefce.ac.uk/analysis/HEinEngland/students / (accessed on 15 July 2018).

Hillman, Nick. 2017. Introduction: Running to stand still? In Where Next for Widening Participation and Fair Access? New Insights from Leading Thinkers. London: HEPI/Brightside, pp. 7-16. ISBN 978-1-908240-29-3.

Home Office. 2017. Syrian Vulnerable Persons Resettlement Scheme and Vulnerable Children's Resettlement Scheme-Arrangements. Written Ministerial Statement, March 22. Available online: https:/ / www.parliament.uk/business/publications/written-questions-answers-statements /writtenstatement/Lords/2017-03-22/HLWS553/ (accessed on 15 July 2018).

Jungblut, Jens. 2017. Refugees Welcome? Recognition of Qualifications Held by Refugees and Their Access to Higher Education in Europe. Country Analyses. In Refugees Welcome? Recognition of Qualifications Held by Refugees and Their Access to Higher Education in Europe. Country Analyses. Brussels: ESU, pp. 71-86.

Kerckhoff, Alan C. 2001. Education and Social Stratification. Processes in Comparative Perspective. Sociology of Education 74: 3-18. [CrossRef]

Könönen, Jukka. 2018. Differential inclusion of non-citizens in a universalistic welfare state. Citizenship Studies 22: 53-69. [CrossRef] 
Koucky, Jan, Ales Bartusek, and Jan Kovarovic. 2007. Inequalities and Access to Tertiary Education: European Countries 1950-2005, Working Paper. Prague: Education Policy Centre.

Law Library of Congress. 2016. Refugee Law and Policy: United Kingdom. Available online: https://www.loc. gov /law / help/refugee-law / unitedkingdom.php (accessed on 15 July 2018).

Lisbon Recognition Convention Committee. 2017. Recommendation on the Recognition of Refugees' Qualifications under the Lisbon Recognition Convention and Explanatory Memorandum. Paris and Strasbourg: Unesco/European Council, November 14.

Lucas, Samuel R. 2001. Effectively maintained Inequality: Education Transitions, Track Mobility, and Social Background. American Journal of Sociology 106: 1642-90. [CrossRef]

Marginson, Simon. 2016. The worldwide trend to high participation higher education: Dynamics of social stratification in inclusive systems. Higher Education 72: 413-34. [CrossRef]

Metcalfe, Amy S. 2009. The geography of access and excellence: Spatial diversity in higher education system design. Higher Education 58: 205-20. [CrossRef]

Migration Observatory. 2017. Migration to the UK: Asylum. Available online: http:/ /www.migrationobservatory. ox.ac.uk/resources/briefings/migration-to-the-uk-asylum/ (accessed on 15 July 2018).

Morgan, John. 2017. UK's 'Lower-Ranked' Universities Take Non-Eu Students Hit. Times Higher Education, February 23. Available online: https://www.timeshighereducation.com/news/uks-lowerranked-universities-take-non-eu-students-hit (accessed on 15 July 2018).

Morrice, Linda. 2009. Journeys into higher education: the case of refugees in the UK. Teaching in Higher Education 14: 661-72. [CrossRef]

Morrice, Linda. 2013. Refugees in higher education: boundaries of belonging and recognition, stigma and exclusion. International Journal of Lifelong Education 32: 652-68. [CrossRef]

Morris-Lange, Simon, and Florinda Brands. 2016. German Universities Open Doors to Refugees: Access Barriers Remain. International Higher Education 84: 11-12. [CrossRef]

Mountford-Zimdars, Anne. 2014. Are Admissions Models for Undergraduate Study Converging among Highly Selective Universities in England and the US? In Higher Education in the UK and the US. Converging University Models in a Global Academic World? Edited by Sarah Pickard. Leiden and Boston: Brill, pp. 91-112. ISBN 978-90-04-26276-8.

OECD. 2017a. United Kingdom. In Education at a Glance 2017: OECD Indicators. Paris: OCDE Editions. Available online: https: / / doi.org/10.1787/eag-2017-71-en (accessed on 26 June 2018).

OECD. 2017b. Germany. In Education at a Glance 2017: OECD Indicators. Paris: OCDE Editions. Available online: https: / / doi.org/10.1787/eag-2017-48-en (accessed on 26 June 2018).

Pew Research Centre. 2016. Number of Refugees to Europe Surges to Record 1.3 Million in 2015. Available online: http: / /assets.pewresearch.org/wp-content/uploads/sites/2/2016/08/14100940/Pew-ResearchCenter-Europe-Asylum-Report-FINAL-August-2-2016.pdf (accessed on 17 May 2018).

Refugee Council. 2013. Short Guide for Advisers on Access to Higher Education. Available online: https:/ /www. refugeecouncil.org.uk/assets/0002/7374/HE_for_advisers_guide_0413.pdf (accessed on 29 March 2018).

Refugee Council. 2014. Employing Refugees. The Documents Required as Evidence of Entitlement to Work in the UK. Available online: https:/ / www.refugeecouncil.org.uk/assets/0003/4097/Employing_Refugees_-_ Guide_to_documents_required_Dec_2014.pdf (accessed on 13 May 2018).

Refugee Council. 2015. Information Pack for Refugees. Available online: https:/ / www.refugeecouncil.org.uk/ what_we_do/refugee_services/new_refugee_advice (accessed on 13 May 2018).

Refugee Council. 2018a. Asylum Statistics Annual Trends. Available online: https:/ /www.refugeecouncil.org.uk/ assets /0004/2566/Asylum_Statistics_Annual_Trends_Feb_2018.pdf (accessed on 15 July 2018).

Refugee Council. 2018b. Glossary. Available online: https://www.refugeecouncil.org.uk/glossary (accessed on 15 July 2018).

Refugee Support Network. 2012. "I Just Want to Study": Access to Higher Education for Young Refugees and Asylum Seekers. Available online: https: / www.refugeesupportnetwork.org/resources/13-i-just-want-tostudy-access-to-higher-education-for-young-refugees-and-asylum-seekers (accessed on 17 July 2018).

Sainsbury, Diane, and Ann Morissens. 2012. Immigrants' social rights across welfare states. In Welfare States and Immigrant Rights: The Politics of Inclusion and Exclusion. Edited by Diane Sainsbury. Oxford: Oxford University Press, pp. 113-34. ISBN 9780199654772. 
Shavit, Yossi, Richard Arum, Adam Gamoran, and G. Menham, eds. 2007. Stratification in Higher Education: A Comparative Study. Stanford: Stanford University Press, ISBN 9780804754620.

Singleton, Alexander D. 2010. Educational Opportunity: The Geography of Access to Higher Education. Farnham: Ashgate Publishing, ISBN 978-0-7546-7867-0.

Stevenson, Jacqueline, and John Willott. 2008. The role of cultural capital theory in explaining the absence from UK higher education of refugees and other non-traditional students. Paper presented at SCUTREA 2008 38th Annual Conference, University of Edinburgh, Whither Adult Education in the Learning Paradigm? July 2-4. Available online: http:/ / www.leeds.ac.uk/educol/documents/172482.pdf (accessed on 20 July 2018).

TestAS. 2016. Test for Academic Studies. Available online: http:/ / refugees.testas.de/en/ (accessed on 12 June 2018).

The Guardian. 2017. Top Universities ‘Incredibly Slow' to Take More Disadvantaged Students—Report, Emmanuel Akinwotu. September 5. Available online: https:/ / www.theguardian.com/inequality/2017/sep/05/topuniversities-incredibly-slow-to-take-more-disadvantaged-students-report (accessed on 16 February 2018).

Thompson, Laura. 2014. A World on the Move: The Benefits of Migration. Speech Given in Brussels on 25 September 2014, on behalf of the International Organization for Migration. Available online: https: / / www.iom.int/speeches-and-talks/world-move-benefits-migration (accessed on 15 July 2018).

Triventi, Moris. 2013. Stratification in Higher Education and Its Relationship with Social Inequality: A Comparative Study of 11 European Countries. European Sociological Review 29: 489-502. [CrossRef]

UK Council for International Student Affairs. 2015. Welfare Benefits for Refugees. Available online: https:/ / www.ukcisa.org.uk/Information-Advice/Fees-and-Money/Welfare-Benefits?q=refugee\& ExactMatch=\#layer-3692 (accessed on 25 June 2018).

Unangst, Lisa, and Bernhard Streitwieser. 2018. Inclusive Practices in Response to the German Refugee Influx: Support Structures and Rationales Described by University Administrators. In European Higher Education Area: The Impact of Past and Future Policies. Edited by Adrian Curaj, Ligia Deca and Remus Pricopie. New York: Springer Open, pp. 277-92. [CrossRef]

United Nations High Commissioner for Refugees. 2015. Higher Education Considerations for Refugees in Countries Affected by the Syria and Iraq Crises. Geneva: UNHCR. Available online: http:/ / www.unhcr.org/publications/education/568bc5279/education-brief-7-higher-educationconsiderations-refugees-countries-affected.html (accessed on 11 September 2018).

United Nations High Commissioner for Refugees. 2017. Global Trends. Forced Displacement in 2016.

UNHCR and Global Monitoring Report. 2016. Policy Paper 26. No More Excuses: Provide Education to All Forcibly Displaced People. Paris: Global Monitoring Report/UNESCO. Available online: http:/ / unesdoc.unesco.org/ images/0024/002448/244847E.pdf (accessed on 11 September 2018).

University World News. 2018. At university I could not escape the shadow of war. Mona Jebril, January 26. Available online: http: / / www.universityworldnews.com/article.php?story=2018012311441314 (accessed on 15 July 2018).

United Nations Data. 2018a. Country Profile. United Kingdom. Available online: http://data.un.org/en/iso/de. html (accessed on 12 April 2018).

United Nations Data. 2018b. Country Profile. Germany. Available online: http://data.un.org/en/iso/gb.html (accessed on 12 April 2018).

Universities UK. 2016a. Working in Partnership: Enabling Social Mobility in Higher Education. The final report of the Social Mobility Advisory Group. London: UniversitiesUK Publishing, ISBN 978-1-84036-367-8.

Universities UK. 2016b. Higher Education in Facts and Figures 2016. Available online: https:/ /www.universitiesuk. ac.uk/facts-and-stats/data-and-analysis/Pages/facts-and-figures-2016.aspx (accessed on 29 July 2018).

Usher, Alex, and Amy Cervenan. 2005. Global Higher Education Rankings: Affordability and Accessibility in Comparative Research. Toronto: Educational Policy Institute.

Usher, Alex, and John Medow. 2010. Global Higher Education Rankings 2010. Affordability and Accessibility in Comparative Perspective. Toronto: Educational Policy Institute.

Vallet, Louis-André. 2010. Expansion des systèmes éducatifs et dynamique des inégalités sociales devant l'enseignement supérieur: Quelques jalons de la recherche comparative en sociologie. Economie et Statistique 433/434: 23-29. [CrossRef] 
Voznesenskaya, Elena D., Galina A. Cherednichenko, and Olga Y. Dymarskaya. 2004. The accessibility of education as a social problem (differential access to tertiary education and the popular attitude to tertiary education). In Accessibility of Tertiary Education in Russia. Edited by S. V. Shishkin. Moscow: Independent Social Policy Institute (NISP).

Zeiter-Grau, Anne-Christel, and Gaële Goastellec. 2017. Cartographie de l'enseignement-apprentissage du français aux requérants d'asile: des enjeux en tension pour l'individu et la société. Babylonia 2017: 75-78. 